\title{
THE SO-CALLED LESBIAN TRIAD: ZEUS, HERA AND DIONYSOS ${ }^{1}$
}

\begin{abstract}
Summary: The aim of this paper is to deal with the so-called Lesbian triad, documented by Sappho and Alcaeus, and to determine the nature of the festival and the sanctuary linked to it. I will deal with the problem of the identity of the gods, probably the same, that is Zeus, Hera and Dionysos in both literary sources. I will tackle also the issue of whether it is possible to talk about a Lesbian triad of gods, as supported since the last century, but that has been questioned recently. I will try to determine the main features of the festival, probably an annual celebration including beauty contests and commemorating the establishment of the Greeks in the island. The location of the holy precinct in which the festival took place has been very controversial, but the more believable hypothesis identifies it with a sanctuary by the name of Messon, located in the center of the island next to the old Pyrrha.
\end{abstract}

Key words: Lesbian triad, Zeus, Hera, Dionysos, festival, sanctuary

\section{INTRODUCTION}

The purpose of the article is to deal with the so-called Lesbian triad, that is Zeus, Hera and Dionysos, in the light of a Sappho's new papyrus (PGC inv. 105, fr. 2, col. II, 9-25, now in the Green Collection, Oklahoma City), published recently by Burris, Fish and Obbink and revisited by West, Ferrari, Neri, Obbink and Lidov. ${ }^{2}$

The paper is divided into three parts. Firstly, I will begin with the presentations of the two literary sources that attest the Lesbian triad, that is, Sappho and Alcaeus.

${ }^{1}$ This contribution is part of the Research Project "El culto dionisíaco en las islas del Egeo y Asia Menor" (FFI 2015-65206-P), funded by the Spanish Ministerio de Economía y Competitividad.

${ }^{2}$ The papyrus is dated at the end of $2^{\text {nd }}$ century CE, beginning of $3^{\text {rd }}$ century CE. BURRIS-FISHOBBINK 2014; WEST 2014; FERRARI 2014; NERI 2014; OBBINK 2016a; LIDOV 2016b. Unfortunately, these two and other articles included in BIERL-LARDINOIS 2016, were published when my article was already in press and I have only been able to include their references in proofreading in a purely testimonial manner. 
Secondly, I will deal with the problem of the identity of the gods and I will tackle also the issue of wheter it is possible to talk about a Lesbian triad of gods, as supported since the last century, but that has been questioned recently. Finally, I will try to determine the nature of the festival and the sanctuary linked to this triad according to the texts.

I will put aside purely philological issues concerning the reconstruction of the fragments because I follow the standard edition of Voigt for Alcaeus' text and the proposals of new editors for Sappho's new text. For clarity, the main texts here cited are included in the next paragraph.

\section{THE LITERARY SOURCES: SAPPHO AND ALCAEUS}

1. Sapph. fr. 17 Voigt $+P G C$ inv. 105, fr. 2, col. II 9-25 + Burris-Fish-Obbink's and West's readings.

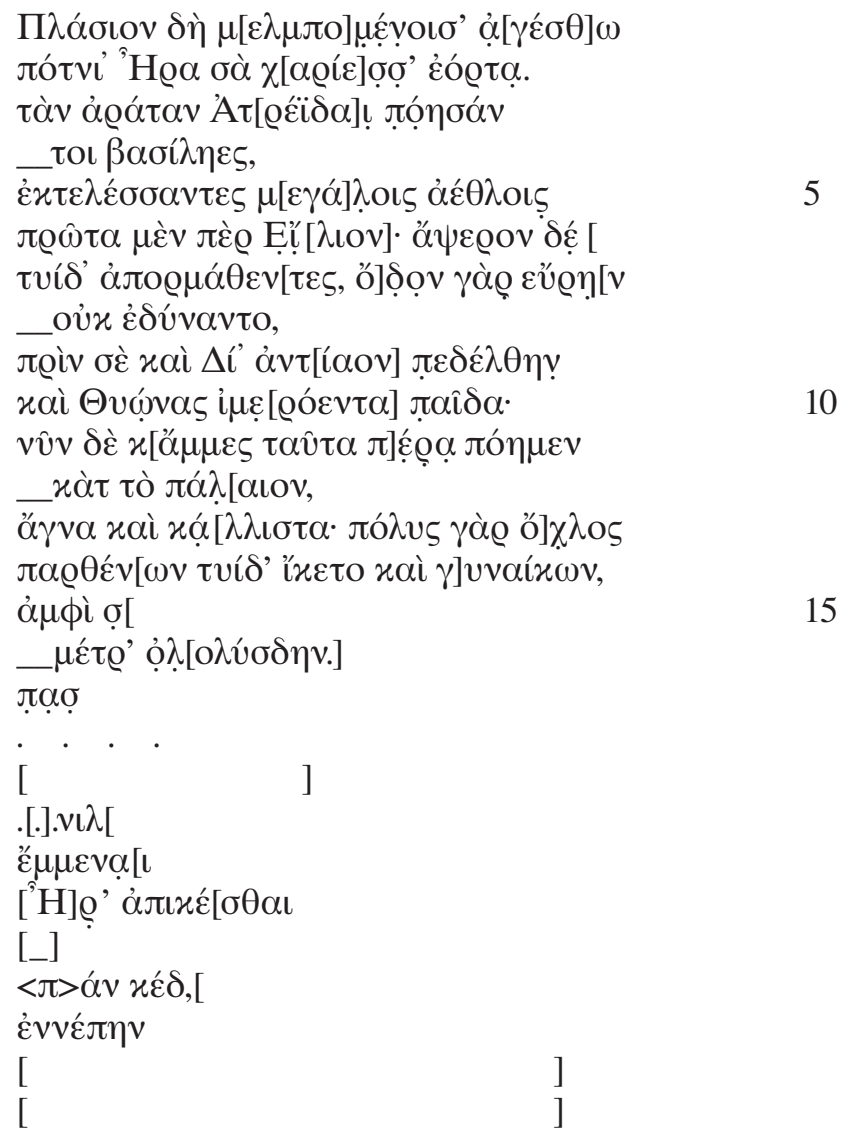


Let your charming festival be celebrated by us singing and dancing nearby, Lady Hera. The Atreides kings established it for you in fulfilment of a vow, after having accomplished great deeds, first around Ilium, and later after having dropped anchor here. For they could not find a way before you and Zeus Antiaos visited, and Thyona's darling son. And now we continue to celebrate these holy and very fair rites in accordance with that ancient precedent. A large crowd of maidens and women comes here ... around (?) ... crying aloud [?] verses? ... to be ... to reach, oh Hera! (Transl. by Burris-FishObbink + West, with variations).

2. Alcaeus fr. 129 Voigt (vv. 1-16)

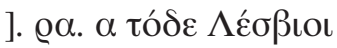

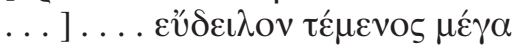

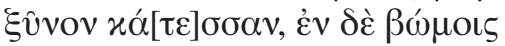

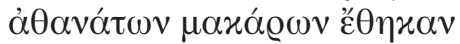

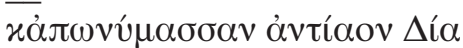

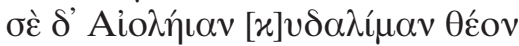

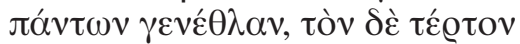

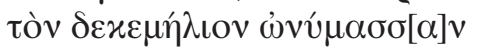

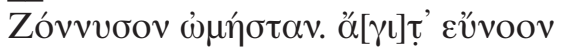

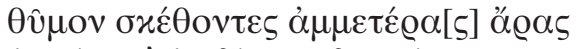

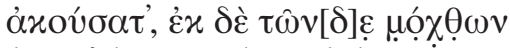

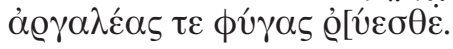

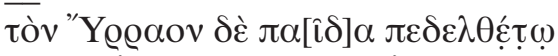

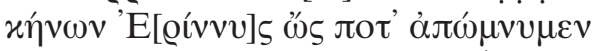

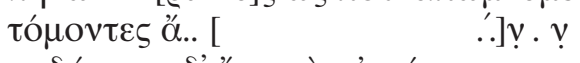

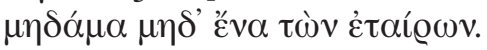

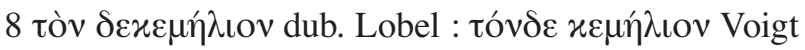

... The Lesbians established this great conspicuous precinct to be held in common, and put in it altars of the blessed immortals, and they entitled Zeus God of Suppliants and you, the Aeolian, Glorious Goddess, Mother of all, and this third they named Dekemelios, Dionysus, eater of raw flesh. Come, with gracious spirit hear our prayer, and rescue us from these hardships and from grievous exile; and let their Avenger pursue the son or Hyrras, since once we swore, cutting ... never (to abandon?) any of our comrades (...) (transl. by Campbell, with a slight variation: Dekemelios instead of Kemelios). 
3. Alcaeus fr. 130 b Voigt (13-20)

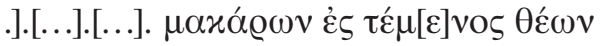

غ̇o! [.....]

$\chi \lambda$ ı.[.].[.].[.]

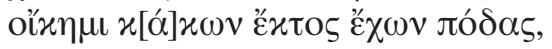

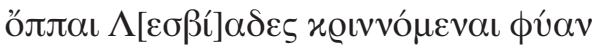

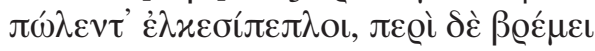

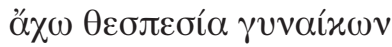

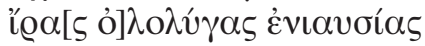

to the precinct of the blessed gods ... treading on the black earth; ... meetings themselves I dwell, keeping my feet out of trouble, where Lesbian women with trailing robes go to and fro being judged for beauty, and around rings the marvellous sound of the sacred yearly shout of women. (transl. by Campbell).

The finding of a new Sappho papyrus has augmented the missing right side of fragment 17 Voigt. $^{3}$ This fragment documented a divine triad integrated by Hera, Zeus and Dionysos that seems to be worshiped by the Atreides in their return from Ilion. The new papyrological findings improve substantially the reading of the text. We read now about

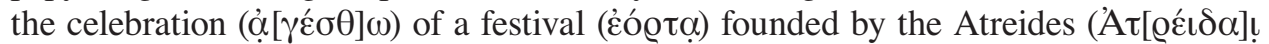

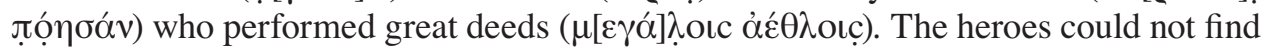

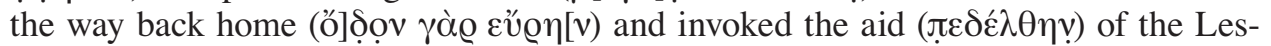
bian triad. For this reason a crowd of maidens and women (ó] $\chi \lambda \circ \varsigma \pi \alpha \varrho \theta \varepsilon ́ v[\omega \nu \ldots$... x ì

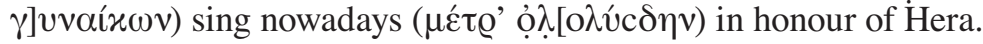

The second evidence of the Lesbian triad is in a poem of Alcaeus (fr. 129 Voigt). ${ }^{4}$ It narrates the building by the Lesbians of a great sanctuary with altars dedicated to Zeus, a female deity and to Dionysos. It seems that Alcaeus took refuge there as a supplicant in exile after participating in a conspiracy against the tyrant Myrsilos. ${ }^{5}$ Alcaeus longs for reintegration into civic life in his native city and prays to the gods to rescue him from exile.

${ }^{3}$ The ancient text was kept in three papyri: vv. 1-20 in P.Oxy. X 1231 fr 1. col. II 2, 2-21 + XVIII 2166 (a) 3; vv. 1-10 in PSI II 123, 3-12; and vv. 4-8 in Oxy. XXI 2289 fr. 9; cf. PAGE 1955, 59; NERI 2014, 11. See now OBbink 2016a, 19-21. These papyri are dated at 50-150 CE (PSI II 123), $2^{\text {nd }}$ century CE (P.Oxy. X 1231 and XVIII 2166 (a)), and at the end of $2^{\text {nd }}$ century CE (Oxy. XXI 2289). LIDOV 2004 and NERI 2014, 12 n. 5 gather the extensive literature about the fragment. See now OBBINK 2016b, 35-36.

${ }^{4}$ Alc. 129, 130a and 130b are kept in Oxy. XVIII 2165 and very fragmentarily in Oxy. XVIII 2166 (c) and Oxy. LIII 3711 fr. 1 col. II 32. PAGE 1955, 163 and HutCHINSON 2001, 92. n. 6 gather the extensive literature about this fragment and 130 Voigt. See now LIDOV 2016a, 64-65.

${ }^{5}$ See PAGE 1955, 167-168. 
Another Alcaeus' fragment (130 a-b Voigt) mentions a precinct of the blessed gods where the poet arrives looking for asylum and where the Lesbian women hold an annual competition for the prize of beauty. The sanctuary was devoted to a plurality of

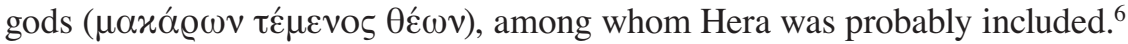

In the ancient Sappho text, a mythical aition to explain the foundation of the cult by the Atreides had already been suggested. ${ }^{7}$ After the fall of Troy, the kings sailed to Lesbos. As they could not find the way back home, they prayed to the divine trinity for help. This version differs slightly from that of the Odyssey, in which the prayer is dedicated to an anonymous deity, perhaps Zeus, and Agamemnon and Menelaus separate before either of them reach Lesbos. ${ }^{8}$ But Sappho's version agrees with Aeschylus' Agamemnon, in which the two brothers leave Ilion together. ${ }^{9}$ Sappho's new version confirms that the Greeks were seeking direction from the gods as to which route to take across the Aegean. ${ }^{10}$ Alcaeus does not mention the myth, but such an aition seems suitable for a man such as him, who cannot come back to home and claim the help of the divinity. ${ }^{11}$

\section{THE THREE GODS}

Most scholars had agreed that the three divinities cited by Sappho (fr. 17. 9-10) are presumably the same as those which appear in Alcaeus (fr. 129). ${ }^{12}$ Let us begin with Zeus.

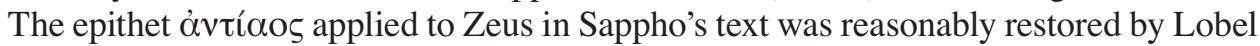
from the Alcaeus' poem (fr. 129. 5). ${ }^{13}$ The term óvtíoos is a happax, but plausibly a

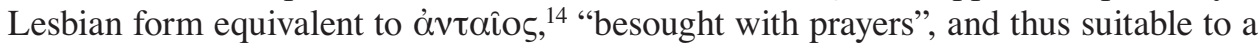
deity who is affording asylum. The new Sappho papyrus has shown that the Atreides

${ }^{6}$ See PAGE 1955, 168.

${ }^{7}$ Deubner 1943, 6; PICARD 1946, 456; PAGE 1955, 60, 168. The genealogical link between the Atreides and the Penthilids of Lesbos is well known: Penthilus, Agamemnon's grandson, was protagonist of the Aeolian colonization, cf. CACIAGLi 2010, 236. See also WeSt 2014, 4 and n. 9.

${ }^{8}$ Od. 3. 130-179. See also Apollod. 6. 1, Procl. Chr. 277-286, cf. PAGE 1955, 59-61; CALAME 2009, 5; 2011, 519; FERRARI 2014, 17-18.

${ }^{9}$ A. A. 615-680, cf. CACIAGLi 2010, 235-236; Ferrari 2014, 18; CACIAGLi 2016, 427.

${ }^{10}$ BurRis-Fish-OBBINK 2014, 6; WeSt 2014, 4; FERRARI 2014, 17-18.

${ }^{11}$ About the date of Alcaeus' exile from ca. 610 BCE to the beginning of $6^{\text {th }}$ century BCE, cf. CACIAGLi 2010, 227 and n. 3. For the concept of helper gods, see LIDOV 2016a, 63-64.

12 Lobel 1941, 31; GallaVotti 1942, 171, 177; DeUBNER 1943, 6-7; PICARD 1946, 455-473; PAGE 1955, 60, 169; Robert 1960, 314; CASADIO 1994, 34 n. 48; Porro 1996, 146; HutCHINSON 2001, 193; CAlame 2009, 4; 2011, 519; CACIAGLi 2010, 228-234; PorRes 2013a, 167; BURRIS-Fish-OBBINK 2014, 5; PirenNE-DEFORGE-PIRONTI 2014, 27-28; Lidov 2016a, 65; NAGY 2016, 476. See, on the contrary, STELLA 1956, 330-331.

${ }^{13}$ LOBEL 1941, 31 n. 1, versus DeUbner 1943, 7. See the same lecture in Sapph. fr. 17 Voigt's edition with other proposals in critical apparatus. On the cult of Zeus in Lesbos, see SHIELDS 1917, 22-27; BuCHHOLZ 1975, 197-199.

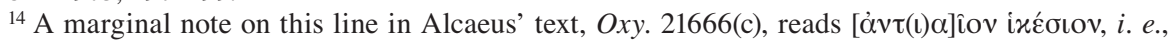

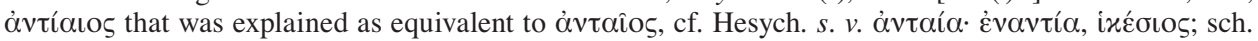

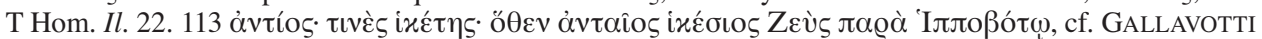
1942, 171; PICARD 1946, 457-458; PAGE 1955, 164; CACIAGLi 2010, 228 n. 9. 
could not find the way back home until they arrived as suppliants ( $\pi \varepsilon \delta \varepsilon \dot{\varepsilon} \lambda \theta \eta \varphi$ ) to the

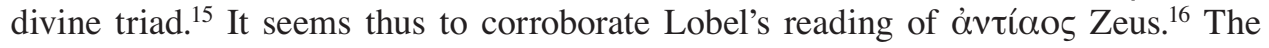
fact that Zeus is invoked in both texts with the same title is a good sign to support the conclusion that we are dealing with the same cult.

Hera is named in Sappho's poem whereas Alcaeus (fr. 129. 6-7) makes reference to a female deity whose name is not mentioned, but, in the light of ancient and new Sapphic text, the reference has been linked to Hera. ${ }^{17}$ Alcaeus called her Aiòń $\iota \alpha v \theta \varepsilon \dot{o v}$,

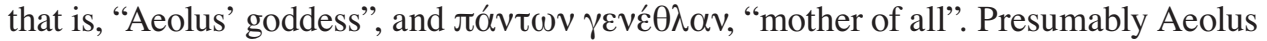
stands as representative of the race of Aeolians, of which he is the eponymous hero. ${ }^{18}$ Hera is the dominant divinity in the mainland home of the Aeolian colonists of Lesbos and attains eminence also in the islands. ${ }^{19}$ In Sappho's poem, the cult is established by the Atreides, who are native to a region in which Hera plays a predominant role. ${ }^{20}$ The

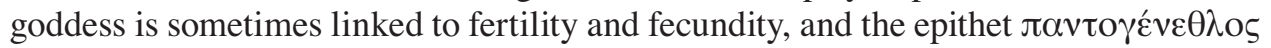
is applied to her in an Orphic Hymn. ${ }^{21}$ A scholium to Alcaeus identifies the sanctuary with a Heraion. ${ }^{22}$ In addition, it is with her name that tradition connected the beauty-contests of Lesbian women, to which I refer later. ${ }^{23}$ The new Sappho text links Hera to a female festival, so that the analogies with Alcaeus' poems become stronger.

The identity of Dionysos raises no doubts. ${ }^{24}$ In new Sappho papyrus (v. 10), we

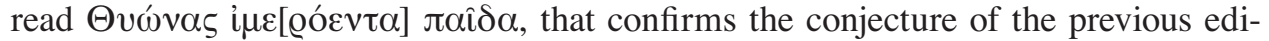

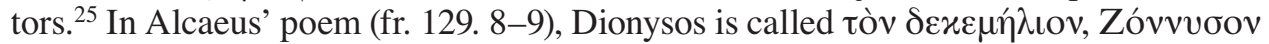

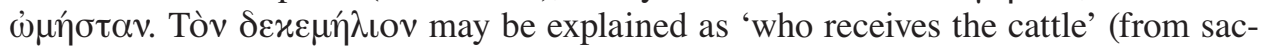
rifice). The phrase has been read also as $\tau o ̀ v \delta \varepsilon \varkappa \varepsilon \mu \eta \dot{\eta} \lambda \iota 0 v$, a cult-title with difficult explanation, perhaps related to $x \varepsilon \mu \alpha$ s, young deer. ${ }^{26}$ The epithet $\omega \mu \eta \dot{\sigma} \sigma \alpha \varsigma$, 'cruel' or

15 The same verb is used in Alc. fr. 129. 19 invoking an Erinnys to appear and come against his

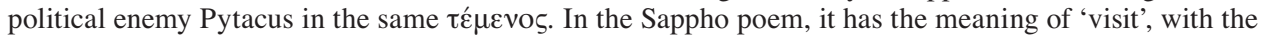
intention of 'beseech', cf. BURRIS-FISH-OBBINK 2014, 21-22; NERI 2014, 17 n. 43.

${ }^{16}$ The reading is kept by BURRIS-FISH-OBBINK 2014, 10; FERRARI 2014, 15; NERI 2014, 19.

${ }^{17}$ Cf. Lobel 1941, 35; Gallavotti 1942, 171-172, 177; DeUbNer 1943, 7; PiCARD 1946, 455462; PAGE 1955, 168; Robert 1960, 313-314; CASAdio 1994, 34; CACIAGLi 2010, 231-234; Porres 2013a, 167-168; LIDOV 2016a, 64-66. See, on the contrary, the reservations of STELLA 1956, 327-334, in order to identify Hera with the Aeolian god cited by Alcaeus. Hera appears in Sappho fr. 9. 4 Voigt and in the new 'Brothers Poem', edited by OBBINK 2014, 32-39.

${ }^{18}$ Cf. Gallavotti 1942, 171; Page 1955, 164; Caciagli 2010, 233.

19 SHIELDS 1917, 27-28; PAGE 1955, 168; BuCHHOLZ 1975, 219-220.

${ }^{20}$ O'BRiEn 1993, 158; CACIAGLi 2010, 233 and n. 31. About the relevance of Hera at Argos and her impact on Lesbos, see NAGY 2016, 460-464, 475.

${ }^{21}$ Orph. H. 16. 4, cf. Deubner 1943, 7; PiCARd 1946, 460-461; PAGE 1955, 164; CACiagli 2010, 231-233.

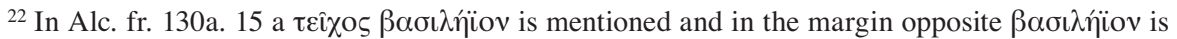

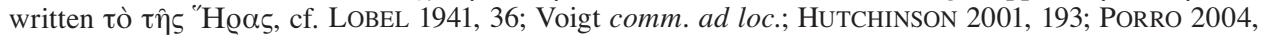
122; CACIAGLi 2010, 231; 2016, 431; NAGY 2016, 458-459.

23 PAGE 1955,168 . See infra $\$ 4$, about beauty contests.

${ }^{24}$ STELLA 1956, 330-331 denied that Thyona's darling son was Dionysos, but her arguments have been disassembled by CACIAGLI 2010, 228-229.

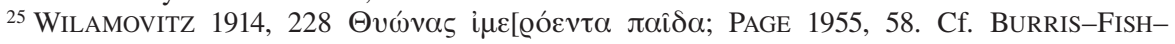
OBBINK 2014, 22.

${ }^{26}$ Regarding both possibilities, see different status quaestionis in CASADIO 1994, 32 n. 46; RodrígueZ SOMOLinos 1998, 156-157; CATENACCI 2007 and PORRES 2013b, 68-72. RodrígueZ SOMO- 
'bloody' better than 'who eats raw meat', evokes probably the wild and bloody side of the god, that has much to do with his role of hunter chasing his prey. ${ }^{27}$ Zóvvvoos, a variant of the god's name, occurs elsewhere in a few late inscriptions in Lesbos. ${ }^{28}$

Accepting that the gods are the same in the Sappho and Alcaeus texts, we can ask about the reasons for the association of these three gods.

\section{DID THESE GODS FORM A TRIAD?}

The triad Zeus-Hera-Dionysos is nowhere else attested. A precedent has been looked for in the Mycenaean triad Zeus-Hera-Drimio, ${ }^{29}$ but it is doubtful that Drimio was a cult-name of Dionysos. The association of Hera with Zeus needs no special comment. The remarkable feature is the admission of Dionysos to this company. Their association in cult has been indeed felt as rare, ${ }^{30}$ because in some places their rites are kept carefully apart. For example, it is forbidden for the priest of Jupiter to touch ivy, and this plant is excluded from the rites of Olympic gods and is not admitted into the precinct of Hera at Athens, and in the same city their priestesses do not speak to each other when they meet. ${ }^{31}$ Nevertheless, these prejudices correspond to local taboos and other reasons have been put forward on behalf of the trinity.

Dionysos had early established worship on the island of Lesbos. ${ }^{32}$ From classical times, the epigraphy attests the celebration of Dionysia in Mytilene, Eressos and Methymna. ${ }^{33}$ Pausanias tells that the dwellers of Methymna had a xoanon, a rude wooden idol fished from the sea, whom the Pythia ordered worshipped as Dionysos

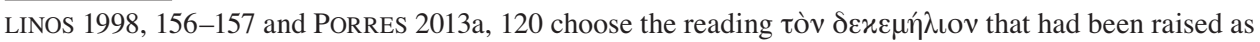

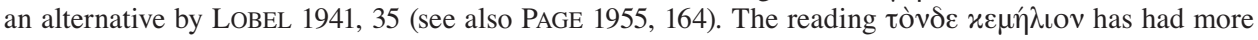
prestige among scholars, but it does not seem to have an easy linguistic and etymological explanation. Among other hypotheses, it has been thought to be an epithet of worship of this sanctuary, perhaps in re-

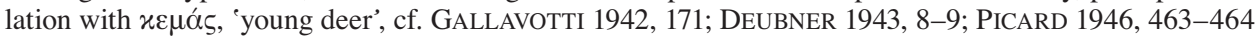
and n. 3; Voigt ad loc.; HUTCHINSON 2001, 32, 198; LIBERMAN 2002², 61-62; GENTILI-CATENACCI $2007^{3}$, 182; CACIAGLi 2010, 229-230 with bibliography. Dionysos is indeed invoked as young deer and kid, cf. JEANMAIRE 1951, 200, 252. See also, the controversial reading $\Sigma \varepsilon \mu \varepsilon \lambda \hat{j i ̈ o v}$ by BEATTI 1956, 189, an unicum attested in Gr. Naz. PG 37. 1571. 12, cf. PORRES 2013b, 69.

${ }^{27}$ See JimÉnEZ SAN CRISTÓBAL, in press 1, with bibliography. On this controversial epithet, cf., ex. gr., DEUBNER 1943, 8; PICARD 1946, 464-465; HeNRICHS 1981, 208-224; CASAdIO 1994, 33 n. 47; LiBERMAN 2002², 62, 128-129, 228; PORRO 2004, 233-235; LEBRETON 2009; CACIAGLi 2010, 230, $237-$ 238; PORRES 2013b, 72-74.

${ }^{28}$ IG XII 2, 69 and 70 (from Mytilene), cf. PAGE 1955, 164-165, with bibliography.

${ }^{29}$ Gallavotti 1956, followed by CASAdio 1994, 29 and n. 39. The idea of a prehellenic triada lies behind PICARD'S 1946 paper. According to KERÉNYI 1976, 187 the Dionysos cult entered into contact with the Hera cult in Argos during the Mycenaean era. See on the contrary, BERNABÉ 2013, 19-20.

30 PAGE 1955, 168-169.

${ }^{31}$ Plu. Quaest. Rom. 290E-291A and fr. 157. 2 Sandbach.

${ }^{32}$ See SHIELDS 1917, 56-67; BuCHHOLZ 1975, 207-211.

${ }^{33}$ Mytilene: $I G$ XII 2. [1] (324-323 BCE); SEG 26. 909 ( $4^{\text {th }}$ BCE) (= IG XII Suppl. 2, $3^{\text {th }}$ BCE); $I G$ XII 2. 18 (end of $3^{\text {th }}$ BCE); IG XII Suppl. 3 (196 BCE); IG XII 2. 15 (193 BCE); IG XII 2. 49 (undated). Eressos: $I G$ XII Suppl. 121 ( $3^{\text {th }}-2^{\text {th }}$ BCE); IG XII Suppl. 125 ( $2^{\text {th }}$ BCE); IG XII 2, 527 [1] (Hellenistic time?); IG XII 2. 528 [1] (Hellenistic time?). Methymna: IG XII 2. 503 (ca. 225-203 BCE). 
himself under the epithet of Phallen. ${ }^{34}$ In Roman Imperial times the Dionysos cult was probably the principal one throughout the whole of Lesbos, as the coins of the Emperor show. ${ }^{35}$ And this is to be expected on the island, so abundant in grapes and so celebrated for his wine. ${ }^{36}$

According to Picard, Zeus and Dionysos accompany Hera, understood as mother goddess of nature, because they are related to a season: Zeus would represent the spring, the season of seeds, while Dionysus would be linked to autumn as the time of the year when harvesting takes place. ${ }^{37}$ But why is Dionysos not related to spring, the season in which he reawakens? ${ }^{38}$ Beyond anthropological or functional interpretations, there are other examples showing the association of Dionysos with the Olympic couple in cult. The same Picard believes that Dionysos could be present in the Heraion of Samos through the branch that adorned the statue of the goddess and through the numerous statues with Dionysiac motifs. ${ }^{39}$ Also in Elis, the sixteen women who organize the festival of Hera invoke Dionysos to appear as a bull. ${ }^{40}$

In myth, the interaction Dionysos-Hera is usual, but we can remember a meaningful episode that Alcaeus himself relates in a hymn probably dedicated to Dionysos, ${ }^{41}$ named here Errapheotes. Albeit fragmentary, it is supposed to tell how Hera was chained by Hephaestus for having cast him out of Olympus, ${ }^{42}$ but that Dionysos managed that a drunken Hephaestus riding a donkey came back and released her. Dionysos demonstrated thus the power of the Dionysiac drink, and Hera therefore had good reasons to be grateful to him as the god of wine.

Wine is also the protagonist of an episode that may link Dionysos to the mythical aition of the Atreides. I am referring to the story of the Oeonotropae (Oeno, Spermo and Elais), three sisters from Delos, progeny of Dionysos. The god gave them the ability to convert into wine, grain and oil, respectively, everything they touched. Agamemnon

${ }^{34}$ Paus. 10. 19. 3; see also, Oenomaus of Gadara apud Eus. PE 5. 36, cf. CASADIO 1994, 34 n. 49 and JIMÉNEZ SAN CRISTÓBAL, in press 2, with bibliography.

35 SHIELDS 1917, 66-67; BUCHHOLZ 1975, 207-208.

${ }^{36}$ SHIELDS 1917, 57. According to Strab. 17. 1. 33 wine was furthermore exported from Lesbos to Naucratis.

${ }^{37}$ PICARD 1946, 469. According to this author (460), the relevance of the goddess, understood by Alcaeus as the creative principle, there would be nothing exceptional, but a feature of the pre-Hellenic triads.

38 OTTO 1997 (1948²) 145-146; PORRES 2013b, 435.

${ }^{39}$ As it is described, for example, by Call. Aitia 4, fr. 101 Pfeiffer, cf. PICARD 1946, 466-468.

40 On the Elean hymn to Dionysos (Carm. Pop. 871 Campbell [PMG 871], transmitted by Plu. Aet. Gr. 299B), cf. BROWN 1982; PORRES 2013b, 436-437, 463 with bibliography. On the festival of Hera, see also Paus. 5. 16. 4, cf. JeAnMAIRE 1951, 216; BURKert 1985, 133, 223; GofF 2004, 96, 192-193.

${ }^{41}$ Alc. 349 Liberman. The fragmentary text has raised discrepancies about the order of the fragments, their assignation to a same poem or the fact that the hymn was dedicated to Dionysos. PAGE 1955, 258-261 considered it a hymn to Hephaestus. See the discussion on LIBERMAN 2002², 152-153.

${ }^{42}$ The myth may be reconstructed from H. Bacch. 1C, Pi. fr. 283 and Paus. 1. 20. 2, among others, cf. SEAFORD 2006, 30-32; PORRES 2013a, 170; 2013b, 328-331. It is interesting that the rare epithet

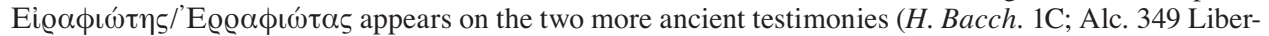
man) in relation with this myth, cf. BERNABÉ 2013c. 
led them on the expedition to Troy to provide supplies to his troops ${ }^{43}$ but Dionysos, listening to their pleas, turned them into doves. The tale shows the importance of wine and the Oenotropae, because of Dionysos in the Atreides' expedition.

On the other hand, we cannot forget that Dionysos is the god of the symposium and that symposium could be a distinct occasion for performing the songs of Alcaeus and Sappho, as rendered by a red-figure vase kept in Munich and attributed to the so-called Brygos Painter. ${ }^{44}$ So the sympotic songs attributed to Alcaeus must also be connected somehow to Dionysos. ${ }^{45}$ As several Alcaeus poems show, ${ }^{46}$ wine played an important role in the political club to which he and his comrades belong. In one of them the poet says that Dionysos gave wine to men so that they could forget their pains, ${ }^{47}$ just as he expresses in fr. 129. 11-12. It would not be so strange that Dionysos was included among the gods to whom the brotherhood make a sacrifice swearing under oath the alliance against Myrsilus, as expressed in fr. 129. $14-16 .^{48}$

In Sappho's text, the presence of Dionysos among Zeus and Hera could also be explained by the relevance of wine in Sappho's mercantile family of wine-traders. We may suppose the existence of a prayer for the safe return of the merchant-gone-to-sea, similar to that included in other fragments of Sappho, as in fr. 5 Voigt and now the 'Brothers Poem', in which the prayer is also dedicated to Hera. ${ }^{49}$ As the gods helped the

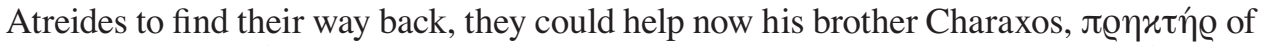
wine on his trips. ${ }^{50}$ The prayer would be based on the formula da quia dedisti. ${ }^{51}$

In conclusion, Zeus as the god of suppliants, Hera as the main divinity of the Aeolians and key deity among the Argives, and Dionysos because of the relevance of wine in the family, the social and political situations of Sappho and Alcaeus could explain the circumstantial existence of the Lesbian triad in their poems. ${ }^{52}$

43 The story is narrated by sch. Hom. Od. 6. 164, that attributes it to Simon. 537 Campbell. See also Ciprias fr. 29 II Bernabé (sch. Lyc. 580), Pherecyd. fr. 140 Fowler and Pàmias (= 196 Dolcetti); Ov. Met. 13. 643-674; Serv. ad Aen. 3. 80, cf. Bernabé 2013b, 49-50; Porres 2013a, 173; 2013b, 184, 353-354.

${ }^{44}$ Antikensammlungen nr. 2416, $A R V^{2} 385$ [228], dated in 480-470 BCE, cf. NAGY 2007, 233235, 248, and 264-265, fig. 1-2. About the sympotic context of some Sappho's poems, see BowIE 2016.

45 NAGY 2007, 213.

${ }^{46}$ Ex. gr., Alc. 38 Voigt, 41 V, 332 V, 333 V, 335 V, 346 V, 347 V, 352 V, 366 V, 367 V, 369 V.

47 Alc. fr. 346 Voigt.

48 GALlaVOTTI 1942, 177.

49 OBBINK 2015, 6. According to him (7), we can glimpse Dionysos as the unnamed protective daimon of line 18 (v. 14) of 'Brothers Poem'. See also OBBINK 2016c, 211-212, 215-217. About the Sappho's prayers for safety, see now LIDOV 2016a, 61-64.

${ }^{50}$ CaCiagli 2010, 238-239.

${ }^{51}$ Pulleyn 1997, 16-18.

${ }^{52}$ Epigraphy and literary testimonies on the sanctuary in question keep quiet about the triad, cf. BUCHHOLZ 1975, 221. 


\section{THE FESTIVAL}

Several scholars assume that the festival cited by Sappho is apparently the same as the one attested by Alcaeus, ${ }^{53}$ and celebrated in the same precinct as the one dedicated to Hera. Let us begin with Sappho's new text. At verse 1, the reading $\Pi \lambda$ ácıov $\delta \eta$

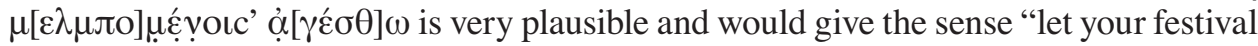
be held by us dancing". ${ }^{4}$ The particle $\delta \eta$ expresses the actuality of the occasion. In

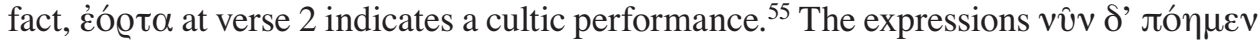

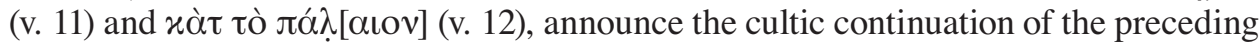
mythical material. ${ }^{56}$ Assuming the supplement of $] \chi \lambda \circ \varsigma$ (v. 13) is correct, the first person

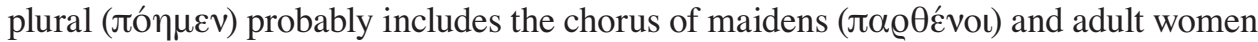

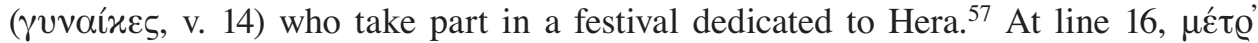
ò $\lambda[0 \lambda u ́ \sigma \delta \eta v]$ may contain a reference to women's ululation, ${ }^{58}$ which may also suggest a choral event. An Alexandrian epigram, perhaps inspired by our Sappho poem, invites the women of Lesbos to dance in the sanctuary of the $\gamma \lambda \alpha u x \omega \hat{\omega} \iota \varsigma$ Hera. ${ }^{59}$ The festival is described in choral terms of song and dance, with Sappho herself pictured as the leader of the chorus. ${ }^{60}$

Let us turn back to Alcaeus. In the second poem (fr. 130), he cites a temenos in which beauty contests were held annually. The festival is typified by the presence of

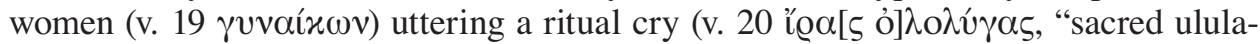
tion"). As in Sappho, the ululation may suggest a choral event. ${ }^{61}$ Sappho and Alcaeus agree on a female celebration with ritual shouting. But could Sappho be referring also

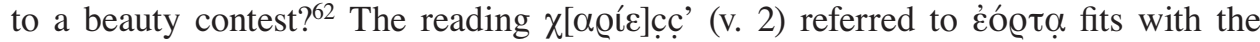

${ }^{53}$ PiCARD 1946, 462-463; BuchHolz 1975, 221-222; Adrados 1986, 316, n. 85; NAGY 2007, 213-215; CALAME 2009, 4; 2011, 519; BurRis-Fish-ObBinK 2014, 5; Neri 2014, 20. See on the contrary CACIAGLi 2010, 248. and n. 75. About the sanctuary, see infra $§ 6$.

${ }^{54}$ BURRIS-FISH-OBBINK 2014, 19; WeSt 2014, 4. See for other conjectures FERRARI 2014, 15; NERI 2014, 18; LIDOV 2016b, 415-418; CACIAGLI 2016, 429-430.

55 As has already been suggested by NAGY 2007, 215; CALAME 2009, 3-7, 2011, 519-520; BURRISFish-OBBINK 2014, 5; FerRaRI 2014, 17; NeRI 2014, 21; NAGY 2016, 483-484. BowIE 2016, 152-153, 156 does not reject a possible interpretation as sympotic prayer which evoked cultic activity.

${ }^{56}$ According to WILAMOVITZ 1914, 228, the poem recounts a foundation myth for a cult in which dances occur. See also CALAME 2009, 3-7; 2011, 519-520.

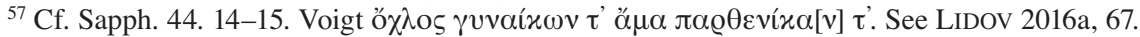

${ }^{58}$ Cf. Alc. 130. 20. See NAGY 1993, 222. On the reading problems of Sappho 16, $\mu \varepsilon ́ \tau \varrho$ ò $\lambda$ [o $\left.\lambda \hat{\sigma} \sigma \delta \eta v\right]$, cf. BURRIS-FISH-OBBINK 2014, 22; WeSt 2014, 4; FERRARI 2014, 18; NERI 2014, 18.

${ }^{59}$ AP 9. 189 (= anon. 33 FGE with comm. ad loc.; test. 59 Campbell), cf. FERRARI 2010, 197-198. The epithet $\gamma \lambda \alpha v x \omega \hat{\pi} ı \varsigma$ could repeat $\gamma \lambda \alpha u ́ x a \varsigma$ of Alc. 129. 26, cf. CACIAGLI 2010, 234.

${ }^{60}$ NAGY 1993, 223.

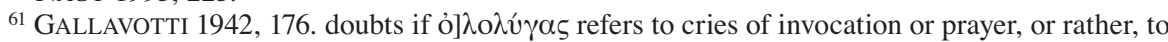
the applause of women winners of the $x \alpha \lambda \lambda \iota \sigma \tau \varepsilon \hat{\imath} \alpha$. Both meanings are attested to ó $\lambda \mathrm{o} \lambda \hat{\zeta} \zeta \omega$. According to $L S J$, ỏ $\lambda \mathrm{o} \lambda v \gamma \eta$ is a loud cry, especially of women invoking a god, and ỏ $\lambda \mathrm{o} \lambda v \gamma \mu$ ó of joy or a song of triumph. In Alcaeus text, the adjective loas suggests to tip the balance to a cultic ritual

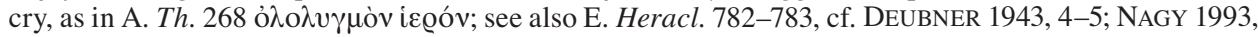
222-223.

${ }^{62}$ As suggested by PICARD 1946, 662, and n. 4; PAGE 1955, 168; NAGY 1993, 222, before the finding of Sappho's new text. CACIAGLI 2010, 239, was skeptical about this possibility. 


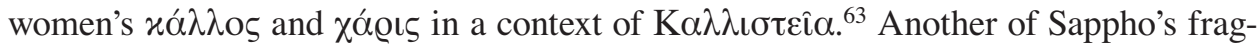
ments praises the beauty of a girl in another maiden and has been explained as an allusion to beauty contests within the thiasos. ${ }^{64}$

The Iliad echoes the outstanding beauty of Lesbian women and the scholia ad

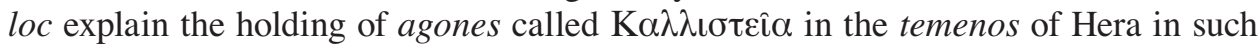
Lesbian cities as Eressos, Methymna, Mytilene and Pyrrha, ${ }^{65}$ just one of the places that has been proposed as the location of our sanctuary. Theophrastus confirms the cele-

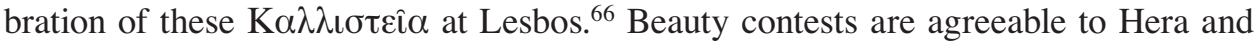
also to Zeus. According to Pausanias, Zeus' priest at Aegium, in Achaia, was chosen from the boys who won the prize for beauty. ${ }^{67}$ And Dionysos also has a remote link

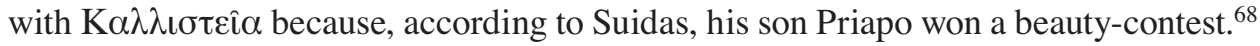
Sappho and Alcaeus may therefore be referring to a beauty contest. It is difficult, however, to find a link between the beauty contests and the Atreides who, according to the mythical section (vv. 2-10 of Sappho's poem), established the festival in fulfilment

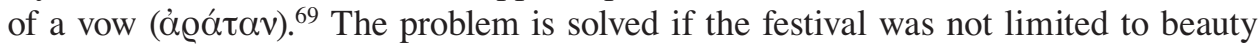

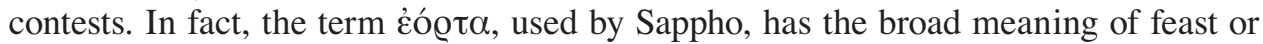
festival, whereas the few extant accounts about beauty contests use the expressions,

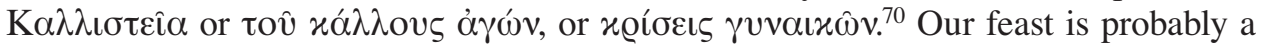
festival in a broad sense, in which different celebrations took place, including beauty contests. We find a parallel example in the historian Nicias ( $1^{\text {st }}$ century BCE), who

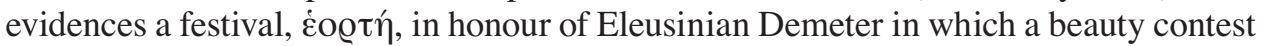
was celebrated. ${ }^{71}$

Let us analyze the data about the sanctuary embracing these rituals before proposing a hypothesis about the kind of festival founded by the Atreides.

${ }^{63}$ Cf. NERI 2014, 14. n. 14.

${ }^{64}$ Sapph. 82a Lobel-Page, cf. Gentili-CATENACCi $2007^{3}, 144$.

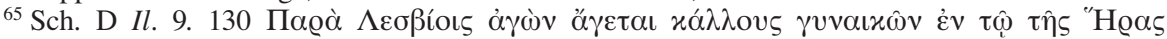

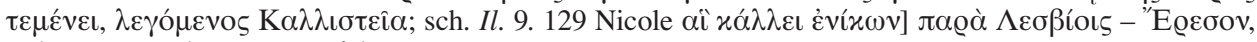

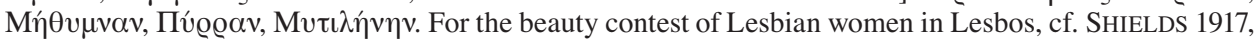
27-28; PICARD 1946, 462 and n. 4; PAGE 1955, 168, n. 4; ROBERT 1960, 314; BuCHHOLZ 1975, 216 and n. 712, 221 and n. 760; LASSERE 1989, 176; NAGY 1993, 222-223; LIBERMAN 2002², 216, n. 138; FERRARI 2010, 198; CACIAGLi 2010, 231, 239; BurRis-Fish-ObBinK 2014, 5-6; Neri 2014, 17, n. 45; CACIAGLI 2016, 428; NAGY 2016, 481-483.

66 Theophrast. fr. 112 Wimmer (ap. Ath. 13. 610a).

${ }^{67}$ Paus. 7. 24. 4.

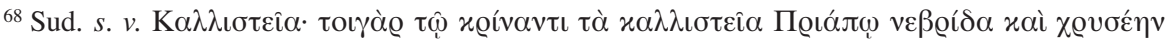
$\tau \eta \dot{v \delta ’ ~ ' ̌ \theta \varepsilon \tau o ~ \pi \varrho o \chi o ́ \eta v, ~ c f . ~ S H I E L d S ~ 1917, ~ 28 ; ~ B U C H H O L Z ~ 1975, ~ 220, ~ a n d ~ n . ~} 749$.

${ }^{69}$ Understood as verbal adjective by WEST 2014, 4; see the discussion in BURRIS-FISH-OBBINK 2014, 19-20; LidOV 2016b, 419-421; CACIAGLi 2016, 430-431. Caciagli thinks (433-437, 445-447) that the festival mentioned in line 2 does not correspond to Kallisteia. In his opinion, the fragment 17 may well have been performed at the shrine of Hera at Messon in the presence of her family and friends and perhaps a wider audience as well.

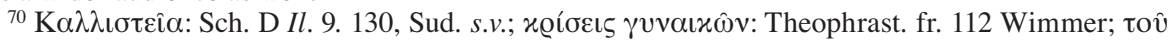

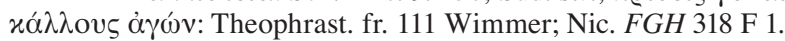

${ }^{71}$ Nic. FGH 318 F 1 . 


\section{THE SANCTUARY}

In fr. 129. 2-3 Alcaeus mentions a holy precinct built for the Lesbians, probably the

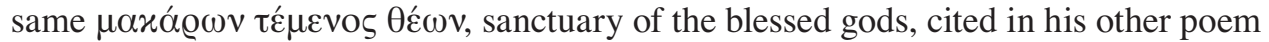
(130b. 13), where Alcaeus looks for asylum and where the Lesbian women go once a year ${ }^{72}$ The poet describes the precinct as a great federal sacred space common (129. 3 govvov) to all the people of the island of Lesbos. ${ }^{73}$ Sappho does not mention a sanctuary, but the content of the poem suggests a festival with a fixed location and date, probably the same as that attested by Alcaeus. ${ }^{74}$ According to the literary evidence analyzed, the sanctuary was a Heraion ${ }^{75}$ whereas altars were dedicated to the three goods. This datum fits with the primacy given to the female deity, as usual in Prehellenic triads, in both Sappho's and Alcaeus' texts. ${ }^{76}$ She it is whom both poets directly address in the second person.

The location of this holy precinct has been very controversial. The temenos is described as $\varepsilon \hat{\delta} \delta \varepsilon \iota \lambda \circ 5$, conspicuous, but not necessarily placed on a peak ${ }^{77}$ a point that has been questioned. ${ }^{78}$ Strabo mentions a Mont Pylaeus, the location of which is unknown but has been linked by some modern scholars with a gloss of Hesychius

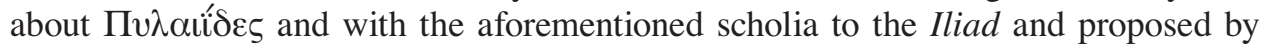
Strabo or by Hesychius as possible location for beauty contests of the Lesbians. ${ }^{79}$ This hypothesis has, however, lost weight in favour of that which places the sanctuary in a fertile plane. ${ }^{80}$ The sanctuary has been also located outside of Lesbos, an unlikely scenario, ${ }^{81}$ because Alcaeus' text underlines the common character of the sanctuary as

72 Gallavotti 1942, 174; Deubner 1943, 13; PiCARd 1946, 462-463; Page 1955, 168, n. 6; Stella 1956, 322-324; RoBERT 1960, 302-307; PORRO 1996, 146; HuTCHINSON 2001, 192-193; LIBERMAN 2002², 61, n. 127; Gentili-CATENACCI 2007³ , 181; CACIAGLi 2010, 227, 231, 238; PorReS 2013b, 428-430; BowIE 2016, 196-200; CACIAGLi 2016, 426.

${ }^{73}$ According to PAGE 1955, 163, there is nothing to show whether to the Lesbians or to the gods is to be understood. But the fact that Lesbians is the subject of the phrase makes more possible the second option, cf. HutCHINSON 2001, 193, 196; CACIAGLi 2010, 243.

74 PiCARd 1946, 462-463; PAge 1955, 168; Robert 1960, 314; CACIAGLi 2010, 227; BurRisFisH-OBBINK 2014, 6; NERI 2014, 21; NAGY 2016, 479.

${ }^{75}$ See the sch. Alc. fr. 130a. 15 cited supra in n. 22.

${ }^{76}$ PICARD 1946, 458.

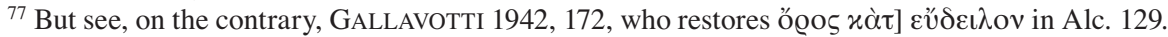

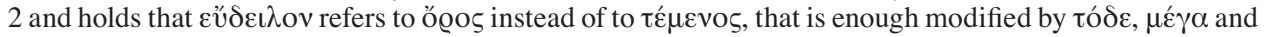
$\xi \hat{v}$ ov. According to him, $\varepsilon \hat{v} \delta \varepsilon \iota \lambda$ os is an attribute for geographic locations, as for example Ithaca in the Odyssey. See also HutCHINSON 2001, 196. Gallavotti's reading is hold by DEUBNER 1943, 6, 14; PICARD 1946, 456, and CASADIO 1994, 30, n. 42 in the idea that Greek sanctuaries outside the city could be located in mountain places (cf. BURKERT 1985, 85). The Mycenaean Heraion, in the Atreides' homeland, was situated on a peek, cf. PICARD 1946, 456.

${ }^{78}$ PAGE 1955, 163. RoBert 1960, 301, with an excellent status quaestionis, 307-308; CACIAGLI 2010, 240-241.

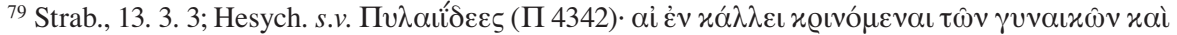

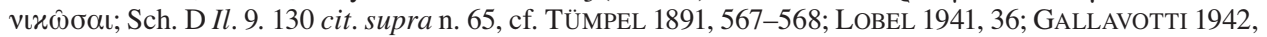
172; Deubner 1943, 4; PiCARd 1946, 462, n. 4; GAllavotTi 1956, 228; LASERre 1989, 169. Hesychius, however, does not circumscribe the notice to Lesbos.

${ }^{80}$ Robert 1960, 311-314; CACIAGLi 2010, 239-240.

${ }^{81}$ VoIGT 1971, 235. ad v. 1s. 
belonging to all the Lesbians, and implies that the place was one of the most important of the island. ${ }^{82}$ Another hypothesis placed the sanctuary near Cape Phokas, ${ }^{83}$ the ancient Bresa, located in the southern part of the West Coast, about three miles southwest of modern Brisa. At Cape Phokas, an inscription "to the Bresagenian Dionysos" was found, dated in the $3^{\text {rd }}$ century BCE. ${ }^{84}$ Here were also found the ruins of an ancient temple that the lexicographers identify as the temple of Dionysos at Bresa, a very ancient foundation attributed to Makar, the legendary first settler in the island and the founder of Dionysos' cult. ${ }^{85}$ But this sanctuary was dedicated exclusively to Dionysos, it was small, and its location was not easily accessible to the majority of the Lesbians. ${ }^{86}$

The more believable hypothesis identifies the precinct with a sanctuary by the name of Messon, mentioned in two inscriptions dated to the second century BCE. ${ }^{87}$ It is located in the present-day Mesa, in the north-western part of the Gulf of Kalloni, in the center of the island next to the old Pyrrha. ${ }^{88}$ In fact, according to a scholium, Alcaeus was forced into exile in this small city. ${ }^{89}$ Pyrrha overlooks a bay with a natural harbour, able to offer a safe haven to such sailors as the Atreides. By the description of Alc. fr. 130, it seems to be located extramuros in a rural setting. In the surrounding area could there be vines, elements consistent with the presence of Dionysos. ${ }^{90}$ The sanctuary has been dated to the first half of the fourth century BCE, although archaeologists determined that there were remains of a previous building. ${ }^{91}$

Messon means "the middle space" and it is in fact located in the centre of the island, ca $35 \mathrm{~km}$ from the capital Mytilene. This area was an important center of communication between the most important cities as Mytilene and Methymna. By its location and function, the holy precinct fits with the description as $\xi \hat{v} v o v$ "common" given in Alcaeus' text (fr. 129) and it seems an appropriate place to celebrate the 'reunions' of Lesbian people (бuvódot, fr. 130b. 15) about which the poet speaks. With

82 CACiagli 2010, 241.

${ }^{83}$ QUINN 1961, 391-393; PICARD 1962, 45-55.

${ }^{84}$ IG XII 2. 478. 2; STELla 1956, 326; CASADIO 1994, 34, n. 49.

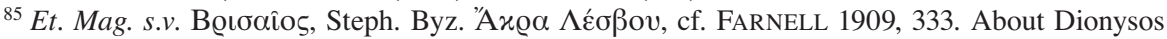
Briseus, cf. FARNELL 1909, 147, 312, n. 104r; SHIELDS 1917, 57-58. On the temple, see KoldEWEY 1890, 63-64; BuCHHOLz 1975, 208, n. 669 with bibiliography. About Makar, see P. Oxy. 53, 3711, col. II 17-27 (=Alc. fr. 306. Ea, col. II 17-27 Liberman); cf. PORRO 2004, 235-236.

${ }^{86} \mathrm{Cf}$. CACIAGLi 2010, 242-243.

${ }^{87}$ IG XI 4. 1064 A 1.5 and B 1. 32. The sanctuary was excavated by KOLDEWEY 1890, 47-61. See also STELla 1956, 322-323; ROBERT 1960, 302-306 with bibiliography; NAGY 1993, 221; LIBERMAN 2002², 61, n. 127; CACIAGLi 2010, 243-248; PiRENNE-DELFORGE - PIRONTI 2014; CACIAGLi 2016, 425-426; NAGY 2016, 458-459. See the objections of PICARD 1962, 55-69 to this location.

${ }^{88}$ RoBert 1960, 305; CACIAGLi 2010, 241. ROBERT 1960, 314, n. 3 wonders about the possible rela-

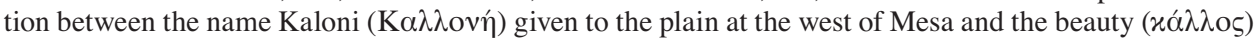
contests celebrated there.

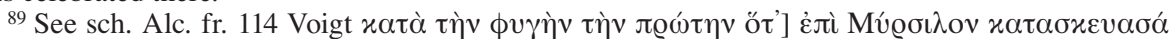

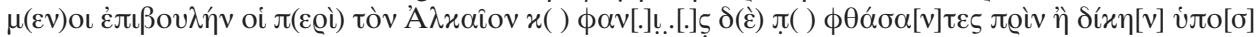

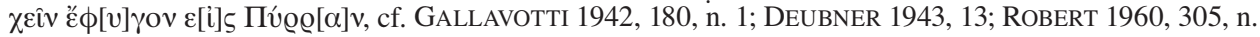
4; GenTILI-CATENACCI 2007³ , 180. See also AdRAdos 1986, 294, 315-316, nn. 84, 91 and 94; CACIAGLI 2010, 245; PORRES 2013b, 428.

${ }^{90}$ CACIAGLi 2010, 245.

${ }^{91}$ Koldewey 1890, 57-58; Robert 1960, 308; CACIAGLi 2010, 247. 
the passing of time, in Hellenistic times, the sanctuary was the seat where the federal judicial activity of the Lesbian league (xoıvóv) and the federal feasts were celebrated. ${ }^{92}$ It has been proposed that the existence of this Lesbian league goes back to the $7^{\text {th }} / 6^{\text {th }}$ century BCE. ${ }^{93}$

\section{CONCLUSIONS}

If we accept the existence of an ancient Lesbian roîvov with seat at the sanctuary of Messon, it seems reasonable that the temenos had a very wide activity and was not limited to beauty contests. Other female festivals cannot be ruled out, such as a festival for Hera with wide participation of women, ${ }^{94}$ to which the festival of the Alexandrian epigram seems to point. ${ }^{95}$ In Sappho's poem the interactions between the past and the present invite us to envisage that the mythic narrative of the return of the Atreides via Lesbos was sung by a choral group of many girls. ${ }^{96}$ The framework for this choral event should be an annual festival commemorating the establishment of the Greeks in the island. Penthilus, grandson of Agamemnon, had a leading role in the Aeolian colonization, and the Penthilids also had a leading political role in Lesbos. ${ }^{97}$ A story like the Atreides myth would seem appropriate to a site reputed to be the landing-place of the original Aeolian settlers and to have served as a central meeting place for representatives of various $\pi$ ó $\lambda \varepsilon \iota \varsigma$ of Lesbos to take council with and to resolve differences between one another. ${ }^{98}$ On the other hand, for a society facing the sea, such a festival offered the possibility of providing protection for the return of sailors and traders.

Alcaeus and, probably, also Sappho are referring to a beauty contest held in the framework of this festival common to all Lesbians. The beauty contests would have had a prominent place which, in turn, could explain the preeminence of Hera in the triad, without forgetting its relevance to the Aeolian island. Dionysos had an early-established worship in Lesbos, a place well known for its wine. The relevance of wine in the family, social and political situations of Sappho and Alcaeus could justify the inclusion of Dionysos in the triad. Although Hera, Zeus and Dionysos interact in

\footnotetext{
${ }^{92}$ Hellenistic decrees (IG XII suppl. 120, 136, 139) indicate that Mytilene, Methymna and Eressos

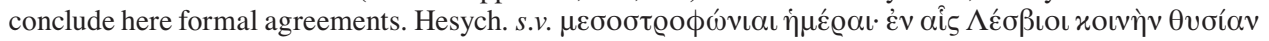
$\dot{\varepsilon} \pi ı \tau \varepsilon \lambda$ ovo 1960, 303-304; COLE 2004, 77-78.

${ }_{93}$ CACIAGLi 2010, 243-245. See also Robert 1960, 308-311.

${ }^{94}$ NERI 2014, 21, n. 71 hypothesizes a wedding of firts class as the song in Sapph. fr. 44 Voigt, but it would not fit with a festival annual as suggested by Alcaeus (fr. 130b. 20). See now the thesis of NAGY 2016, 480-481.

${ }^{95}$ See supra $\S 4$ and n. 59. It is not necessarily linked to beauty contests, as ROBERT 1960, 312, and n. 4 indicates.

${ }^{96}$ CALAME 2011, 520. See now NAGY 2016, 464-468.

${ }^{97}$ Ephor. FGrHist 70 fr. 119. 5, cf. PAGe 1955, 149-150; Ferrari 2010, 24-25; CACIAGLi 2010, 236; 2016, 432-433.

98 As BuRRIS-Fish-OBBinK 2014, 6 hold. They think also that Alc. 129 and 130b likely refer to such meetings rather than to assemblies back in Mytilene, as assumed by PAGE 1955, 177-178.
} 
myths and cults, there is no evidence of this triad except in Sappho and Alcaeus. In its current state, it is prudent to argue that the festival held in the temenos of Messon was dedicated to Hera, while Zeus and Dionysos probably had altars as other gods. While we wait for new documents that provide additional data, we can speak only of a circumstantial Lesbian triad.

Ana Isabel Jiménez San Cristóbal

Departamento de Filología Griega y Lingüística Indoeuropea

Universidad Complutense de Madrid

Spain

\section{BIBLIOGRAPHY}

AdRAdos, F. R. 1986: Lírica griega Arcaica. Poemas corales y monódicos, 700-300

a. C. Introducciones, traducciones y notas. Madrid

BeAtTI, A. 1956: A note on Alcaeus fr. 129. Classical Review n. s. 6, 34, pp. 189-191.

BERnABÉ, A. 2013: Dioniso en los documentos micénicos. In Bernabé, A. - Jiménez

San Cristóbal, A. I. - Santamaría, M. A. (eds): Dioniso. Los orígenes. Textos e imágenes de Dioniso y lo dionisíaco en la Grecia antigua. Madrid, pp. 13-27.

BERnABÉ, A. 2013b: Dioniso en la épica griega arcaica. In Bernabé, A. - Jiménez

San Cristóbal, A. I. - Santamaría, M. A. (eds): Dioniso. Los orígenes. Textos e imágenes de Dioniso y lo dionisíaco en la Grecia antigua. Madrid, pp. 29-85.

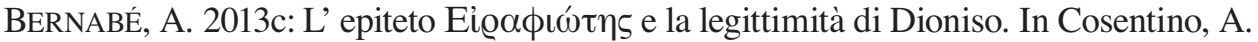
- Monaca, M. A. (a cura di): Studium sapientiae. Atti della giornata di studio in onore di Giulia Sfameni Gasparro, 28 gennaio 2011. Soveria Mannelli, pp. 57-73.

Bernabé, A. - Jiménez San Cristóbal, A. I. - SAntamaríA, M. A. (eds) 2013:

Dioniso. Los orígenes. Textos e imágenes de Dioniso y lo dionisíaco en la Grecia antigua. Madrid

Bierl, A. - LARdinois, A. (eds) 2016: The Newest Sappho: P. Sapph. Obbink and P. GC inv. 105, frs 1-4. Leiden-Boston

BowIE, E. 2016: How Did Sappho's Songs Get into the Male Sympotic Repertoire? In Bierl, A. - Lardinois, A. (eds): The Newest Sappho: P. Sapph. Obbink and P. GC inv. 105, frs. 1-4, Leiden-Boston, pp. 148-164.

Brown, CH. 1982: Dionysus and the Women of Elis: PMG 871. Greek, Roman and Byzantine Studies 23, pp. 305-314.

BuchHolz, H. G. 1975: Methymna. Archäologische Beiträge zur Topographie und Geschichte von Nordlesbos. Mainz

BURKERT, W. 1985: Greek Religion. Archaic and Classical. Oxford

BurRis, S. - Fish, J. - OBBINK, D. 2014: New Fragments of Book 1 of Sappho. Zeitschrift für Papyrologie und Epigraphik 189, pp. 1-28.

CACIAGLI, S. 2010: Il temenos di Messon: uno stesso contesto per Saffo e Alceo. Lexis 28, pp. 227-256. 
Caciagli, S. 2016: Sappho Fragment 17: Wishing Charaxos a Safe Trip? In Bierl, A. Lardinois, A. (eds): The Newest Sappho: P. Sapph. Obbink and P. GC inv. 105, frs 1-4. Leiden-Boston, pp. 424-448.

CAlame, C. 2009: Referential Fiction and Poetic Ritual: Towards a Pragmatics of Myth (Sappho 17 and Bacchylides 13). Trends in Classics 1, pp. 1-17.

CAlame, C. 2011: The Semiotics and Pragmatics of Myth. In Dowden, K. - Livingstone, N. (eds): A Companion to Greek Mythology. Oxford, pp. 519-524.

CAmpBell, D. A. 1990: Greek Lyric. 1, Sappho and Alcaeus. Cambridge, MA

CASADIO, G. 1994: Storia del culto di Dioniso in Argolide. Roma

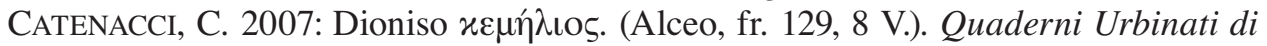
Cultura Classica 85, pp. 37-39.

Cole, S. G. 2004: Landscapes, Gender, and Ritual Space. The Ancient Greek Experience. Berkeley

DEUBNER, L. 1943: Zu den neuen Bruchstücken des Alkaios. Abhandlungen der Preußischen Akademie der Wissenschaften Pr 7, pp. 3-14. (=Deubner, O. [Hrsg.]: Kleine Schriften zur klassischen Altertumskunde. Königsten, 1982, pp. 691-704).

FARNELL, L. R. 1909: The Cult of the Greek States. Vol. V. Oxford [repr. 2005]

FERrARI, F. 2010: Sappho's Gift: The Poet and Her Community. Ann Arbor (=Una mitra per Kleis. Saffo el il suo pubblico. Pisa, 2007).

FERRARI, F. 2014: Saffo e i suoi fratelli e altri brani del primo libro. Zeitschrift für Papyrologie und Epigraphik 192, pp. 1-19.

GAllaVOTTI, C. 1942: Studi sulla lirica greca: 5. Nuovi carmi di Alceo da Ossirinco. Rivista di filologia e di istruzione classica 70, pp. 161-181.

GallavotTi, C. 1956: La triade lesbia in un testo miceneo. Rivista di filologia e di istruzione classica 84, pp. 225-236.

Gentili, B. - CAtenacci, C. $2007^{3}$ : Polinnia. Poesia Greca Arcaica. Messina-Firenze

GoFF, B. 2004: Citizen Bacchae. Women's Ritual Practice in Ancient Greece. Berkeley HenRICHS, A. 1981: Human Sacrifice in Greek Religion: Three Case Studies. In Rudhardt, J. - Reverdin, O. (éd.): Le sacrifice dans l'Antiquité. Genève, pp. 195235.

Hutchinson, G. O. 2001: Greek Lyric Poetry. A Commentary on Selected Larger Pieces. Oxford

JeAnMaIRe, H. 1951: Dionysos. Histoire du culte de Bacchus. Paris 1951 [repr. 1978] JiMÉNEZ SAN CRISTÓBAL, A. I. in press 1: Dionysus Omestes: from Alcaeus to Plutarch. JimÉnEZ SAN CRISTÓBAL, A. I. in press 2: Fiestas dionisíacas en Lesbos. In Jiménez San Cristóbal, A. I. (ed.): Los antiguos se van de fiesta. Aspectos de las fiestas en el mundo mediterráneo

KERÉNYI, K. 1976: Dionysos, Archetypal Image of Indestructible Life. Princeton

Koldewey, R. 1890: Die antiken Baureste der Insel Lesbos. Berlin

LASSERRE, F. 1989: Sappho. Une autre lecture. Padua

Lebreton, S. 2009: Dionysos Ômèstès (Plutarque, Thémistocle, 13; Antoine, 24). In Bodiou, L. et al. (éd.): Chemin faisant. Mythes, cultes et société en Grèce ancienne. Mélanges en l’ honneur de Pierre Brulé. Rennes, pp. 193-203. 
Liberman, G. 2002²: Alcée. Fragments. Paris [1991¹]

LIDOV, J. 2004: Hera in Sappho, fr. 17 L-P, V - and Aeneid I? Mnemosyne 57, pp. 387-406.

LidOV, J. 2016a: Songs for Sailors and Lovers. In Bierl, A. - Lardinois, A. (eds): The Newest Sappho: P. Sapph. Obbink and P. GC inv. 105, frs. 1-4. Leiden-Boston, pp. 55-109.

LIDOV, J. 2016b: Notes on the First Stanza of Fragment 17. In Bierl, A. - Lardinois, A. (eds): The Newest Sappho: P. Sapph. Obbink and P. GC inv. 105, frs. 1-4. Leiden-Boston, pp. 415-423.

LoBEL, E. 1941: The Oxyrhinchus Papyri, Part XVIII. London

NAGY, G. 1993: Alcaeus in sacred place. In Pretagostini, R. (a cura di): Tradizione e innovazione nella cultura greca da Omero all' età ellenistica. Scritti in onore di B. Gentili. Vol. I. Roma, pp. 221-225.

NAGY, G. 2007: Did Sappho and Alcaeus ever Meet? Symmetry of Myth and Ritual in Performing the Song of Ancient Lesbos. In Bierl, A. - Lämmle, R. - Wesselmann, K. (Hrsgg.): Literatur und Religion 1. Wege zu einer mythisch-rituellen Poetik bei den Griechen. Berlin - New York, pp. 211-269.

NAGY, G. 2016: A Poetics of Sisterly Affect in the Brothers Song and in Other Song of Sappho. In Bierl, A. - Lardinois, A. (eds): The Newest Sappho: P. Sapph. Obbink and P. GC inv. 105, frs. 1-4. Leiden-Boston, pp. 449-492.

NERI, C. 2014: Una festa auspicata? (Sapph. fr. 17 V. e P. GC. inv. 105 fr. 2 c. II rr. 9-28). Eikasmós 25, pp. 11-24.

ObBink, D. 2014: Two New Poems by Sappho. Zeitschrift für Papyrologie und Epigraphik 189, pp. 32-49.

OBBInK, D. 2015: Provenance, Authenticity, and Text of the New Sappho Papyri. Paper read at the "Society for Classical Studies" Panel: "New fragments of Sappho". New Orleans, 9 January, pp. 1-37. [www.papyrology.ox.ac.uk/Fragments/SCS. Sappho.2015.Obbink.paper.pdf]. Last view 27/01/2016.

OBBink, D. 2016a: The Newest Sappho: Text, Apparatus Criticus, and Translation. In Bierl, A. - Lardinois, A. (eds): The Newest Sappho: P. Sapph. Obbink and P. GC inv. 105, frs. 1-4, Leiden-Boston, pp. 13-33.

ObBink, D. 2016b: Ten Poems of Sappho: Provenance, Authenticity, and Text of the New Sappho Papyri. In Bierl, A. - Lardinois, A. (eds): The Newest Sappho: P. Sapph. Obbink and P. GC inv. 105, frs. 1-4, Leiden-Boston, pp. 34-54.

OBBINK, D. 2016c: Goodbye Family Gloom! The Coming of Charaxos in the Brothers Song. In Bierl, A. - Lardinois, A. (eds): The Newest Sappho: P. Sapph. Obbink and P. GC inv. 105, frs. 1-4, Leiden-Boston, pp. 208-224.

O'BRIEN, J. V. 1993: The Transformation of Hera. Lanham, MD

Отто, W. F. 1997: Dioniso. Mito y culto. Madrid (Dionysos. Mythos und Kultus, Frankfurt 1948²)

Page, D. L. 1955: Sappho and Alcaeus. An Introduction to the Study of Ancient Lesbian Poetry. Oxford

PAGE, D. L. 1981: Further Greek Epigrams. Cambridge (FGE) 
PICARD, CH. 1946: La triade Zeus-Héra-Dionysos dans l'Orient hellénique d'après les noveaux fragments d'Alcée. Bulletin de Correspondance Hellénique 70, pp. 455-473.

PICARD, CH. 1962: Où fut à Lesbos, au VII ${ }^{\mathrm{e}}$ siècle, l' asyle temporaire du poète Alcée? Revue archéologique, pp. 43-69.

PIRENnE-Delforge, V. - PIRONTI, G. 2014: Héra et Zeus à Lesbos: Entre poésie lyrique et décrit civique. Zeitschrift für Papyrologie und Epigraphik 191, pp. 27-31.

PORRES, S. 2013a: Dioniso en la lírica griega arcaica. In Bernabé, A. - Jiménez San Cristóbal, A. I. - Santamaría, M. A. (eds): Dioniso. Los orígenes. Textos e imágenes de Dioniso y lo dionisíaco en la Grecia antigua. Madrid, pp. 117-193.

PORRES, S. 2013b: Dioniso en la poesía lírica griega, Tesis doctoral. Madrid [http:// eprints.ucm.es/24575/1/T35156.pdf]. Last view 27/01/2016.

Porro, A. 1996: Alceo. Frammenti. Firenze

PORRO, A. 2004: Alcaeus. In Bastianini, G. et al. (edd): Commentaria et lexica graeca in papyris repertae. Pars. I: Comentaria et lexica in auctoris. V. 1 AeschynesAlcaeus. München-Leipzig, pp. 75-246.

Pulleyn, S. 1997: Prayer in Greek Religion. Oxford

QuinN, J. D. 1961: Cabe Phokas, Lesbos. Site for an archaic sanctuary of Zeus, Hera and Dionysus? American Journal of Archaeology 65, pp. 391-393.

ROBERT, L. 1960: Recherches épigraphiques. Inscriptions de Lesbos. Revue des études anciennes 62, pp. 285-315 (=Opera Minora Selecta 2. Amsterdam 1969, pp. 801-831).

RodríGUEZ SOMOLINOS, H. 1998: El léxico de los poetas lesbios. Madrid

SEAFORD, R. 2006: Dionysos. London-New York

SHIELDS, E. L. 1917: The Cults of Lesbos. Menasha, Wisconsin

Stella, L. A. 1956: Gli dei di Lesbo in Alceo fr. 129 LP. La Parola del Passato 46, pp. 321-334.

TÜMPEL, K. 1891: Lesbiaka. Philologus 50, pp. 566-568.

VoIGT, E. M. 1971: Sappho et Alcaeus. Amsterdam

West, M. L. 2014: Nine poems of Sappho. Zeitschrift für Papyrologie und Epigraphik 191, pp. 1-12.

WilamovitZ-MOEllendORFF, U. VON 1914: Neue lesbische Lyrik (OxyrrinchusPapyri X). Neue Jahrbücher für klassische Altertum 33, pp. 225-247. 